\title{
PARAXIS ON GEOGRAPHY EDUCATION IN NEPAL
}

\begin{abstract}
Shambhu Prasad Khatiwada ${ }^{1}$
Abstract

This paper attempts to analyze the paradoxical view on geography education in Nepal. Praxis interplays the relationships between theory and practice-reflection in action in any academic discipline, like geography education. Geography education demonstrates the strategic linkages of content and pedagogy in teaching and research activities. Even now, geography occupies an important place not only in schools but also in university curricula. However, the easier it is to define geography, the harder it is to define geography education. Butt (2011) includes both parameters of geography (as a discipline) and education (as an activity) in the definition of geography education. This paper fulfills the objectives through systematic reviews of appropriate literature related to geography education. For this purpose, 50 documents were searched from different sources, such as Google, abstracts, keywords, and books. Only 15 papers and books were selected that gave pace to theories, methods, and pedagogical practices in geography education. The findings of this paper show that the definition of geography education is limited only to teaching geography in schools and colleges. In addition, teaching requires content knowledge (subject matters) related to geographic concepts, themes, traditions, tools and techniques, and contemporary issues related to climate change, environmental degradation, disasters, etc., in the curriculum. Pedagogical knowledge is also equally essential to deliver that content effectively to learners. Thus, geography provides the basis for choosing what content to teach at a particular level and, geography education helps to select teaching methods. It shows that the first is focused on the content and the second on pedagogy.
\end{abstract}

Keywords: Praxis, geography education, human-environment, teaching-learning, content knowledge, pedagogical practices.

\section{Introduction}

The connotation of geography education has derived from the intersection of two academic domains: geography and education. It becomes a subfield of geography

1 Dr. Khatiwada is a Professor, Department of Geography Education. T.U. Nepal, E-mail: geography.dmc@gmail.com 
(Bednarz, 2010). The literal meaning of geography is to describe the earth, while education refers to the process of receiving or giving systematic instruction. Education is the fundamental process of reproduction of a discipline. Geography education is the study of spatial variations in the provision, take-up, quality of, and outputs from educational facilities and resources for the instruction in the schools and universities (Gregory, 2009 p. 186).

Geography Education Specialty Group (GESG) defined geography education in 1999 as follows:

"to promote research on the lifelong development of knowledge about the world through geography; to develop the theory and foster the practice of teaching and learning geography in formal and informal educational contexts; and to be an advocate for geographic literacy" (cited in Bednarz, Downs \& Vender, 2003 p. 461).

Butt (2011) includes both parameters of geography (as a discipline) and education (as an activity) in the definition of geography education. Geography education incorporated both domains of geographic knowledge and competencies and education. It is geographic education. Knowledge is at the core of geography education, and it is a foundation of teaching and learning formally and informally. Geography education is different, and it is not geography per se but is, instead, about geography teaching, learning, thinking, and related cognitive and educational processes (Bednarz, Downs \& Vender, 2003 pp. 461-62). Indeed, geography education provides a comprehensive relationship between pedagogic approaches (teaching models), teaching strategies, techniques, and methods creating the conditions for learning to inform lesson design (Chalmers, Keown \& Kent, 2002; Jones \& Lambert, 2013).

Geography education covers complex concepts understood by explaining its relationship to the discipline of geography, detailing its aims and place in formal and non-formal education, and considering its essential components, such as subject matter, skills, and perspectives (Gerber, 1990 p. 6). Jones and Lambert (2013) argue that geography teachers need two things: a concept of geography and an idea of education (p.5). Teachers' understanding of a subject matter and ability to share information with students comes from the foundations of learning gained from geography. Geography provides enriching knowledge to illustrate essential concepts, themes, and perspectives essential for curriculum design or the selection of contents. The organization of curriculum provides a linear marc of content topics through scope and sequence. The range of teaching may be designed to encourage learning processes (memory, attention, observation) and 
cognitive skills (reasoning, comparing and contrasting, classification), as well as the acquisition of specific information, such as the names of the letters of the alphabet (Wiggins and McTighe, 1998). From this point of view, geography education has three essential components: curriculum, methodology, and techniques. It designs to promote the repertoire of cognitive and affective skills to socialize children (Chalmers, Keown \& Kent, 2002; Jones \& Lambert, 2013).

In Nepal, various scholars and organizations have also contributed to the development of geography education. Jay Prithvi Singh was the first person who contributed to the development of geography education in the school curricula. However, the history of geography education in Nepal dates back to the Vedic period (Subedi \& Poudel 2005). The people have been using the concepts of geography knowingly or unknowingly in their everyday life (Singh, 2016). Geography as a discipline was treated with the opening of Durbar High School (1852) and Tri-Chandra College (1918). Since then, geography has been aught continuously at school, campus, and university levels in Nepal. Nevertheless, the departure of Nepalese geography education was flourishing with the affiliation of the Indian university (Budathoki, 1993; Subedi \& Joshi 1997; Subedi \& Poudel 2005; Subedi, 2014; Jawali et al. 2015; Khatiwada, 2019).

Geography has taught continuously in Nepal with the College of Education (1956), Geography Department (1964), and Geography Education Department in Tribhuvan University. The reorganization of the Faculty of Education at Tribhuvan University and recommendations of various National Education Commissions have also been playing a significant role in the development of geography education (Subedi \& Joshi 1997; Subedi, 2014). Their findings revealed that geography education working on varied themes and the progress of Nepalese geography has been credible since the 1960s in both content and pedagogy.

These studies have attempted the historical development of geography education but have not covered paradoxes on this theme. It requires an analysis of the paradoxical views on geography education to clarify geography and geography education, components of geography education, theoretical base of geography education in the case of Nepal. Thus, the focus of this paper attempts to analyze the multifaceted nature of understanding geography education and to clarify the relationship between content and pedagogy from a geographical perspective. 


\section{Methods and Materials}

This paper is based on the mixed methods research design and both qualitative and quantitative approaches. Several decisions were applied to collect information, such as the selection of learning resources regarding geography, geography education, critical pedagogical approach, research works on geography education, and the existing curriculum of both school and higher levels. In this paper, 50 documents were searched from different sources such as the Google scholar, Pro-Quest database, and Google browser using Preferred Reporting Items for Systematic Reviews and Meta-Analyses (PRISMA) model. PRISMA model is an evidence-based minimum set of items for reporting in systematic reviews and meta-analyses. The PRISMA focuses on the definition of research questions, selection of inclusion and exclusion criteria, search for databases, refinement of collected data, and extraction of information from relevant data to the research question (Alonso-Garcia, Aznar-Diaz, Caceres-Reche, TrujilloTorres, \& Romero-Rodriguez, 2019). PRISMA also reports the effects of interventions and systematic reviews with objectives rather than other evaluations (prisma-statement. org/). Out of the total searched documents, only 15 papers were included for systematic reviews using inclusion and exclusion criteria, which have given pace to geography education. This paper is used both descriptive and analytical methods for data analysis.

\section{Results and Discussion}

Geography and Geography Education: I have frequently used to ask myself question distinguished between geography and geography in various competitive exams. Today I am also constantly asking the same question. However, I do not know the exact paradoxical answer. The literature repeatedly answered that geography is focused on content and pedagogy in geography education. This answer does not satisfy me as I go deeper I guess this difference is due to the philosophical, theoretical, and methodological debates. In my opinion, the focus of geography is to contribute to geographical knowledge production through teaching and research and blending geographic knowledge and pedagogy in teaching-learning and educational research in geography education. In this perspective, these two are complementary to each other. Indeed, they seem to be competition in practice. It made dualism for paraxis. It needs clarification of the definition of geography and geography education.

There is still no clear concept between geography and geography education. However, available literature defines geography as a discipline, and geography education is a subfield of geography. Geographical knowledge has been developing since ancient times, and it seems to have gained recognition as a scientific genre in modern times. Various 
scholars and institutions have contributed by developing their worldview and scientific methods for teaching learning and geographic research. They have given their invaluable efforts and innovative ideas to scientific geography. Nevertheless, there seems to be very little work done in the field of geography education. Chorley \& Haggett (1970) have clearly stated that geography focuses on the content and geography education on pedagogy.

Geography brings together physical and human dimensions of the world- people, places, and environments (Peet, 1998). However, Clifford et al. (2009) claimed that the subject of geography encompasses many concepts and is difficult to define in a single word ( $\mathrm{p}$. xiii). Singh (2016) states that geography is a hallmark of first-hand learning about the world and encompassing discipline to understand the human and natural complexities. Geography is a synthetic study of the relationship between human societies and the earth's surface, such as spatial, area studies, earth science, and human-land interactions (Pattison, 1964; Holt-Jensen, 2009). The Pattison (1964) academic traditions are still dominant in geography (Rosenberg, 2019). Clifford et al. (2009) considered that the key concepts, such as space, place, time, scale, landscape, nature, systems, globalization, development, and risks, are the core of geography (p. xv). Thus, geography defines

'Geography is the study and science of environmental and societal dynamics and society-environment interactions as they occur in the real world. The character and spatial relations of a specific place and processes have influenced geographic investigations in a hierarchy of geographic scales' (Gaile \& Willmott, 2003 p.1).

As stated in the background, geography education embraces two different domains: geography and education. Graber (2009) argued that geographical education plays the role bridge the natural and the social sciences for implementing pedagogical purposes to use their environments. The author explores the complex nature of geographical education to understand its relationship to the discipline of geography with its aim and place in both formal and non-formal education. For geography education, such a perspective was centered in the 2016 International Charter (IGU-CGE):

"There was an overarching belief among experts that geography education would develop a positive international worldview among learners. At the time, a positive worldview included knowledge about the physical environment, the diversity of cultural groups who inhabited those environments. Over the years, the details of research and writing about international understanding and an informed worldview became more defined, presented greater clarity, and reflected the dynamism of the discipline of geography. Geographers weave ideas from human and physical 
aspects of the discipline to describe and explain how the world works" (cited in Brooks, Qian, \& Salinas-Silva, 2017, p. 6).

The IGU-CGE (2016) further clarifies that:

"Geography Education enables students to critically analyze the world about them. International understanding is an essential product of the study of geography since understanding requires meaningful knowledge. The meaningful knowledge is necessary to make important decisions about the immediate and long human and environmental conditions on earth" (cited in Brooks, Qian, \& Salinas-Silva, 2017, p. 6).

Reinfried and Hertig (2011) defines;

"Geographical education is a scientific discipline grounded in the domain of geography and education, which looks into the conditions, principles, and methods of domain-specific teaching and learning. It is engaged in the structuring of the subject matter and the content- and skill-related application of appropriate pedagogical approaches to induce deep learning and cognitive development" (p. 3).

Based on these definitions, it can conclude that geography education is a scientific discipline that integrates both the domains of geography (content) and education (pedagogy). Geography education has also played a role in creating a geographical worldview and dealing with contemporary geographic questions and challenges, such as international migration, global social inequalities, disaster, and climate change (Demirci, González \& Bednarz, 2018 p. v).

There is provides a reciprocal relationship between geography and geography education. Content and pedagogical knowledge are equally essential for teaching and geographic research. Geographical concepts and themes are the basis for choosing a subject matter (content) for teaching geography. Geography is a driving force that shapes geography for pedagogical practices. Butt (2011) argued that geography is a discipline and education is an activity. The National Council for Geographic Education and the Association of American Geographers developed five themes in 1984 to facilitate the instruction of geography in K-12 (as the first kindergarten (K) and last (twelfth) grades. These themes are location, place, human-environment interaction, movement, and region. 


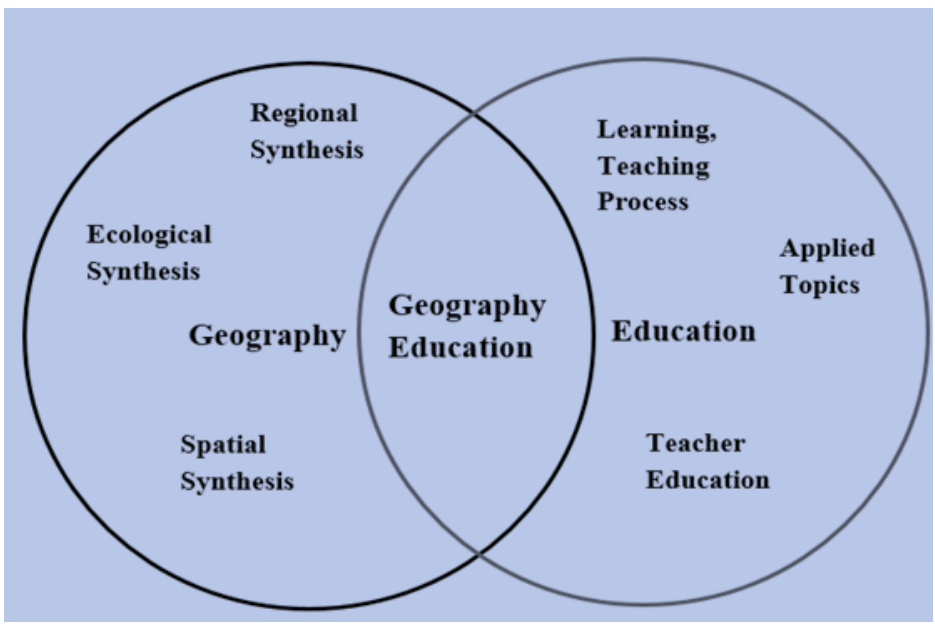

Figure 1 represents a conceptual idea of geography and education, adopted from Bednarz, 2002, p. 131

Figure 1 shows the two separate discs of geography and education. The intersection of these two discs creates a sub-field of geography education. It is shaped the subdomains of education (learning theory, teacher education, or applied topics) with geography by the intersection (Bednarz, 2002). The synthetic descriptions of spatial, ecological, and regional perspectives; and geography education compromises a complex web of pedagogical knowledge (setting learning objectives, curriculum design, selection of teaching methods, teaching-learning activities, and evaluation of learning outcomes). In addition, research on the contemporary issues of geography education is also a field of geography education. Thus, the argument of Jones \& Lambert (2013) 'teachers of geography need a concept of geography, and education is still prominent in the paraxis of geography and geography education.

Geography Education in Vedic Period: In the 508th Mantra of the Sama Veda, 'Vicharshani: Hitah Sa Chetati' ('वचिर्षणा: हतिः स चेततf'), that is, the knower imparts knowledge by being beneficial. The wise become the knower. His sole purpose in imparting knowledge is to benefit others. The darkness of knowledge is disappearing from understanding. Because everything is clear, the path of his progress is wide. Students send to school for education. Later, they self-sufficient and motivated their disciples through knowledge (Luitel \& Dahal, 2017, p. 265). In this Mantra, Veda has clarified the role of teachers, educators, and students. Sages were the seers of the Vedas and taught the pupil in the Sanyaasram. 


\section{|| 24 || The Third Pole: Journal of Geography, Volume 20 - 21, 2021}

In the Vedas, deity, sage, and mantra are three important subjects. The deities worshiped as a form of nature and natural substances (Luitel \& Dahal, 2017). Rais and Limbus of the indigenous peoples of eastern Nepal have celebrated festivals each year, and known as Udhauli and Ubhauli Parwa. The essence of this festival is related to local livelihood and resource utilization. They followed the seasonal rhythm of upward (in summer), downward (in winter) livestock and agricultural activities. They worshiped nature is so that good health prevails, people and livestock did not get sick, no calamity over centuries. This tradition is widely practiced in different communities of Nepal that transcended the geography curricula.

Place of Geography Education in School and University Level: Geography is an essential school subject (Lambert \& Morgan, 2010). It is a vital subject as the meeting place of nature and man, science and the humanities (Adamson, 1920, p. 30). Globally, it has taught either as an independent subject or within an integrated framework. Epistemically, geography is an inclusive subject. Geography is encompassed the entire observable domain of the earth's surface and is taught in different universities curricula (Alam, 2016, p. 17).

Various scholars, professional organizations, and academic institutions have contributed through teaching, research, and symposiums to establish geography as a genre. They have given pace to flourish geography at school and university levels. Their tasks focused on curriculum development, textbook writings, teacher training, research, and organizing seminars and workshops to create knowledge, understanding, and teaching applied knowledge at various levels (Martin, 2005).

In Nepal, various scholars and organizations have also contributed to the development of geography education. Among them, Jay Prithvi Singh's name is at the forefront. He was the first to include geography in the school curriculum. The establishment of Durbar High School (1852) and Tri-Chandra College (1918) were legitimated teaching geography at the school and college levels. The departure of Nepalese geography education was flourished with the coordination of the Indian university curriculum and teachers.

The establishment of the College of Education (1956) and Tribhuvan University (1959) have given pace to the continuity of geography education at a higher level. The credit goes to the teacher-training program at the College of education, Geography Department (1964), the recommendations of National Education Commissions, the organization of the Faculty of Education at Tribhuvan University, and the establishment of the geography education department to the continuity and changes in geography education in Nepal. 
Geography was introduced as a compulsory subject in school and an optional subject in university curricula after the National Education System Plan (1971). It became an optional subject at both school and university levels in 1981.

Nature of Geography Education Curriculum: The nature of the curriculum includes the instructional program as indicated by the course offerings to meet the various requirements of a diverse population, the courses of study, embodying outlines of knowledge taught, and all the experiences provided under the guidance of the school or university level. Geography is an inclusive discipline, the content of geography derived from various subjects in the sciences, social sciences, and humanities. However, geography is still categorized whether in the natural or the social sciences (Bhog et al., 2012 cited in Alam, 2016, p. 17).

In Nepal, the Faculty of Education (FoE) has introduced a semester-based curriculum at the Master in Education (M.Ed.) level since 2015. FoE designed 69 credit hours courses, and it is grouped into core areas ( 21 credits), specialization course (39 credits), and thesis and practicum ( 9 credits). Geography education is a specialized subject, which offers 39 credit hours (13 Courses) for M. Ed. Level. The courses are grouped into six dimensions for pedagogical purposes. For example, environmental dynamics (geomorphology, climatology, and mountain geography) in the first. Human-society dynamics (population geography) in the second. Environmental society dynamics (human dimension of global change, environmental geography, and geography of resource management) is in the third. Regional geography (geography of Nepal and geographic perspectives on inequality, gender, religion, justice, value, and belief systems) is in the fourth. Geographic methods (Geographic Information System, Remote Sensing, Global Positioning System, surveying, cartography, and statistical methods) in the fifth; and geographers at work (teaching geography, disaster management, tourism geography, history of geographical thoughts, and thesis writing) in the last. Indeed, the geography curriculum of Indian universities has comprised physical geography, human geography, regional geography, application of information and communication technology, and fieldwork (Nangia, 2001).

Geography Education as a Pedagogical Science: Teaching occurs in several contexts or milieu such as individual, group, class, school, community. Three significant attributes of the actors' capacities, actions, and thoughts are potential determinants of teaching and learning in the classroom (Shulman, 1986). Teachers of geography need concepts of geography and education (Jones \& Lambert, 2013 p.5). The teachers require mastery in content knowledge (CK) and pedagogical knowledge (PK) for successful teaching. 
Content knowledge and pedagogical knowledge refer to what to teach and how to teach. It is known as pedagogy content knowledge (PCK).

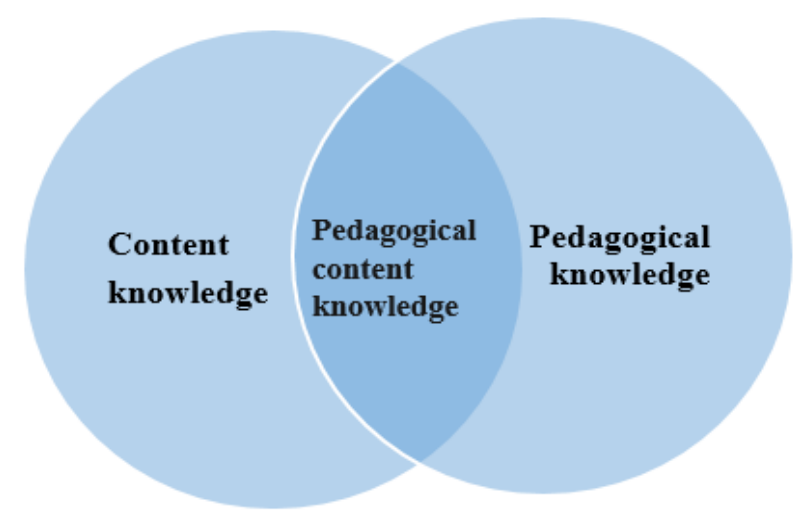

Figure 2: An Illustration of Pedagogical Content Knowledge, adopted and modified from Shulman (1986:1987)

Shulman has first introduced the concept of pedagogical content knowledge (PCK) in 1986. The author blended both domains of content knowledge and pedagogy knowledge to produce a Venn diagram and the interception known as Pedagogical Content Knowledge (Fig. 2). It is also known as the missing paradigm in the study of teaching. Shulman (1986) argues that 'if teaching is an art, its practice requires at least three different forms of knowledge: rules of principles, knowledge of particular cases, and knowledge of ways to apply appropriate regulations in teaching learning.

Content Knowledge (CK): Subject matters have selected from different branches of geography for designing the 13 courses. Thus, geography teachers should know what to teach (facts, concepts, theories, and perspectives) in geography, known as content knowledge. Shulman $(1986 ; 1987)$ argued that the first source of the knowledge base is content knowledge - the knowledge, understanding, skill, and disposition are learned by schoolchildren. I have given an example of mountain geography. The teacher should know the fundamental concepts of mountains and understand the problems and prospects of mountain terrain blends geography and the dynamic environments of mountains. Thus, the following syllabus under which the Geography Education Department operates specific subject matter (content knowledge) taught at the M.Ed. Level (Table 1). In this article, I have presented only a model of the first unit of mountain geography. 


\section{Table 1: Specific objectives and contents}

\begin{tabular}{|c|c|}
\hline Specific objectives & Contents \\
\hline $\begin{array}{l}\text { To introduce the meaning and } \\
\text { definition of mountain and mountain } \\
\text { geography } \\
\text { - To explain the nature and scope of } \\
\text { mountain geography } \\
\text { - To discuss the approaches to the } \\
\text { study of mountain geography } \\
\text { - To discuss mountains as dynamic } \\
\text { environments: biophysical, } \\
\text { sociocultural, and political conditions } \\
\text { of mountain regions. }\end{array}$ & $\begin{aligned} & \text { Mountain and mountain geography } \\
& \text { i. } \text { Meaning and definition } \\
& \text { ii. } \text { Nature and scope } \\
& \text { iii. } \text { Approaches } \\
& \text { iv. } \text { Dynamic environments of } \\
& \text { mountains } \\
& \text { - } \text { Cultural } \\
& \text { - } \text { Political, } \\
& \text { - } \text { Biophysical }\end{aligned}$ \\
\hline
\end{tabular}

Source: Department of geography education, 2020

Table 1 shows the content knowledge of mountain geography at the master level. Thus, the teacher should know what to teach in the first unit of mountain geography at the M. Ed. Level.

Pedagogical Knowledge (PK): Pedagogical knowledge includes the methods, strategies, and techniques of teaching in the classroom. Teachers can use various teaching methods, skills, and approaches in teaching mountain geography. Teaching requires classroom management, student participation, teacher-student interaction, assessing and evaluating students' performance, etc. Thus, pedagogical knowledge covers those broad principles and strategies of classroom management and organization that appear to transcend subject matter for achieving desirable outcomes.

There is no mention of classroom management and student participation in teaching mountain geography. However, the teachers have used different teaching methods, strategies, and approaches according to the nature of the units. The teacher can use lecture, question answer, discussion, observation, class assignment, and presentation techniques in this course.

Pedagogical Content Knowledge (PCK): Pedagogical Content Knowledge (PCK) is the third component of geography education. It is a unique type of knowledge that teachers relate to their subject matter or content knowledge with pedagogical knowledge. It is the interweaving of subject matter, methods of teaching, and learning in the classroom. This knowledge enables the learner to grasp, comprehend, reason, transform and reflect on the body of the knowledge presented (Shulman, 1986). 


\section{|| 28 || The Third Pole: Journal of Geography, Volume 20 - 21, 2021}

The first unit of mountain geography seems to have made the following arrangements for teaching. This unit provides concepts and ideas of mountains and mountain geography through visual aids, physical maps, Google Earth, and models blending both contents and pedagogical knowledge.

Evaluation: Evaluation is an essential component of geography education. It gives meaning to predicted desirable outcomes of the curriculum. It looks at curricular objectives for predicting what and how was accomplished. For this purpose, both formative and summative evaluation can apply to assess the value or effectiveness of the curriculum. In the syllabus of mountain geography, student achievement seems to be measured by internal and external evaluation, of which 40 percent marks for internal and 60 percent in external evaluation. Internal evaluation includes attendance, presentation, and assignments by the teacher, and paper-pencil test (including multiple-choice, short answers, and long answer questions) in external examination by the office of the Dean. The Department of Geography Education seems to have prepared a specialization schedule. It guides the teacher from which lesson to ask knowledge (30\%), mid (40\%), and higher $(30 \%)$ orders questions.

Research in Geography Education: The researcher makes richness to geography education where the Third Pole yearly published since 2000. It aims to publish scholarly and research-oriented articles on any aspects of geography and geography education contents and pedagogy (DGE, 2002). Virtually Geographic Journal (The Third Pole) has been published by Geography Education Departmental Editorial Teams and limited papers published in the themes of teaching-learning and research in geography education (Table 1). However, publications are reflected the different geographic themes from various departments. It meant that geographers needed new horizons open to all colleagues in the same department to publish their research papers in geography education. There is likely a much poorer publication base and a weaker research tradition in geography education (Pohkrel, 2013; Khatiwada, 2019). Although, the editorial committees have given liberty to researchers for choosing their research topics. This free access to scholars has strongly influenced research traditions in geography education. Another issue was the lack of institutional representation of geography. The institutionalization of geography as an academic discipline was considered crucial for organizing meetings and conferences, increasing networking opportunities among geographers, and developing relations with public and governmental institutions. Besides, geographers have complained about the lack of platforms to freely in discussion and debate geographical research. 
Table 2: Research activities in geography education

\begin{tabular}{|c|c|c|}
\hline Journal & Number of articles in geography education & $\begin{array}{l}\text { Volume and } \\
\text { published year }\end{array}$ \\
\hline $\begin{array}{l}\text { The Third Pole } \\
\text { Journal of Geography } \\
\text { (Department } \\
\text { of Geography } \\
\text { Education, T. U.) }\end{array}$ & $\begin{array}{l}\text { 1. Geography education in Nepal: An } \\
\text { overview } \\
\text { 2. Enrollment and distribution of disabled } \\
\text { at primary school in Nepal } \\
\text { 3. Geography education and research in } \\
\text { Nepal: Challenges, status, and options } \\
\text { 4. Space of geography content in social } \\
\text { studies of school education curriculum, } \\
\text { 5. Availability and utilization of } \\
\text { instructional materials in teaching } \\
\text { geography in secondary schools }\end{array}$ & $\begin{array}{l}\text { Vol. 2, } 2002 \\
\text { Vol. 11-12, } 2012 \\
\text { Vol. 13, } 2013 \\
\text { Vol. 17, } 2017 \\
\text { Vol. 17, } 2017 \\
\end{array}$ \\
\hline $\begin{array}{l}\text { Nepalese Journal of } \\
\text { Educational Studies: } \\
\text { A publication of the } \\
\text { Central Department } \\
\text { of Education, T. U. }\end{array}$ & $\begin{array}{l}\text { 1. Teaching geographic concepts in social } \\
\text { studies: Perspectives on teaching- } \\
\text { learning } \\
\text { 2. Distance to primary school participation } \\
\text { in Palpa district } \\
\text { 3. Geography education in Nepal some } \\
\text { issues and challenges }\end{array}$ & $\begin{array}{l}\text { Vol. 1, } 2011 \\
\text { Vol. 1, } 2011 \\
\text { Vol. 2, } 2015\end{array}$ \\
\hline $\begin{array}{l}\text { Institutional Research } \\
\text { (Department } \\
\text { of Geography } \\
\text { Education, T. U.) }\end{array}$ & $\begin{array}{l}\text { 1. Geography education in Nepal some } \\
\text { issues and challenges } \\
\text { 2. Promotion of Local/Indigenous } \\
\text { Knowledge for disaster risk reduction } \\
\text { managementin Sudur Paschim Province, } \\
\text { Nepal: An educational perspective }\end{array}$ & $\begin{array}{l}2015 \\
2020 / 21 \text { on } \\
\text { going }\end{array}$ \\
\hline
\end{tabular}

This paper has also sampled 16 Master's thesis in geography education. The result indicates that only six scholars have attempted issues of teaching geography in secondary schools. The topics are related to geography teaching in school (1997), selection of geography as an optional subject at school level (1997), analysis of secondary school geography textbook (1999), problems of graduate-level geography subject of the faculty of education (1999), condition of geography teaching in the secondary schools (2000) in different parts of the country.

\section{Conclusion}

It can conclude that the paraxis between content knowledge and pedagogical knowledge are dual transmitting mastery of teaching-learning in the classroom. However, But in 
Nepal, the subject and teaching have not been integrated yet. It can argue that the contents and pedagogical knowledge are separate. Therefore, geography education does not seem to have achieved specialization in any of the contents or pedagogy. This condition also applies to mountain geography. Thus, geography educators should internalize this limitation, and both content and pedagogy should competently blend to prepare pedagogical content knowledge to revive the meaning in the geography curriculum. It develops geographical knowledge, skills, and attitudes and facilitates socializing future citizens. Both geography theories (positivism, humanism, post-modernism, and so on) and learning theories (behaviorism, cognitivism, constructivism, and critical ideas) help to formulate epistemology in geography education.

\section{References}

Adamson, J. E. (1920). The place of geography in the school curriculum. South African Geographical Journal, 4 (1), pp. 30-32. Retrieved from https://doi.org/10.1080/ 03736245.1920. 11882215.

Alam, S. F. (2016). Place of geography in the school curriculum. Geography and you. Retrieved from https://www.researchgate.net/publication/303495585

Bednarz, S. W., Downs, R. M., \& Vender, J. C. (2003). Geography education. In G. L. Gaile and C. J. Willmott (Eds.), Geography in America: At the dawn of the 21st century, pp. 679-690). Oxford, UK: Oxford University Press.

Bednarz, S. (2010). Geography education research in the journal of geography 19881997. International research in geographical and environmental education, 9 (2):128-140 DOI:10.1080/10382040008667641

Brooks, C., Qian, G., \& Salinas-Silva, V. (2017). What next for geography education? A perspective from the International Geographical Union, Commission for geography education. Journal of research and didactics in geography (J-READING), 1(6), pp. 5-15.

Burathoki, G. B. (1993). The teaching of geography in our schools. Geographer's point. Kathmandu: The Center for Nepalese Geography, 2 (2), pp. 22-26.

Butt, G. ed. (2011). Geography, education, and the future. London: Continuum International Publishing Group.

Chalmers, L., Keown, P. \& Kent, A. (2002). Exploring different 'perspectives' in secondary geography: Professional development options - CORE Reader. International research in geographical and environmental education, 11, No. 4. Retrieve from https://core .ac.uk/download/pdf/29196090.pdf ·

Clifford, N. J., Holloway, S. L., Rice, S. P. \& Valentine, G. eds. (2009). Key concepts in geography. California: SAGE Publications Ltd. 
Chorley R. J. \& Haggett, P., eds. (1970). Frontiers in geographical teaching. Routledge.

Demirci, A., González, R. M. and Bednarz, S. W. eds. (2018). Geography education for global understanding. Switzerland: Springer International Publishing AG.

DES (1990). Geography for ages 5-/ 6. Final report of the geography National Curriculum Working Group. London: HMSO.

Gaile, G. L \& Willmott, C. J. eds. (2003). Geography in America at the dawn of the 21st century. New York: Oxford University Press.

Geographical Association (2008). Concepts in geography. Retrieved from https://www. geography. org.uk/Concepts-in-geography.

Gerber, R. (1990). Geographical Education. Geography, I. Retrieve from https://www. eolss.net/Sample-Chapters/C01/E6-14-01-03.pdf

Gregory, D., Johnston, R., Pratt, G., Watts, M. J. \& Sarah (2009). The Dictionary of human geography. John Wiley \& Sons Ltd.

Holt-Jensen, A. (2009). Geography history and concepts: A students' guide. London: SAGE Publication LTD.

Jnawali, D., Poudel, K. P., Rijal, S. P., Dhakal, K. R., Awasrhi, T. P., \& Sigdel, T. P. (2015). Geography education in Nepal: Some issues and challenges. Nepalese Journal of educational studies: A publication of the central department of education, 2 (1), pp. 15-24.

Jones, M. \& Lambert, D. (2013). Debates in geography education: London: Routledge.

Khatiwada, S. P. (2019). Status and barriers of classroom-based student assessment practices in geography at secondary level in Nepal. Interdisciplinary education research, 4 (2):123-131.

Morgan, J. \& Lambert, D. (2010). Geography: Teaching school subjects 11-19. New York: Routledge Francis and Taylor Groups.

Luitel, T. P. \& Dahal, R. (2017). Chaar Vedako sar (The essence of the four Vedas). Kathmandu: Manjari Publications.

Martin, G. J. (2005). All possible worlds: A history of geographical ideas. New York: Oxford University Press.

Nangia, S. (2001). Curriculum development committee in geography. India: CDC in Geography.

Pattison, W. D. (1964). The four traditions of geography. Journal of geography, 63, pp. 211-216.

Peet, R. (1998). Modern geographical thought. UK: Blackwell Publishers Ltd. 
Pokhrel, K. P. (2013). Geography education and research in Nepal: Challenges, status, and options. The Third Pole: Journal of Geography Education, 13, pp. 39-45.

Reinfried, S. \& Hertig, P. (2011). Geographical education: How human-environmentsociety processes work. http://www.geoeduc.ch/files_publi/reinfried_hertig_ 2011.pdf

Rosenberg, M. (2019). The four traditions of geography. Retrieve from https://www. thoughtco.com/four-traditions-of-geography-1435583

Singh, R. B. ed. (2016). Progress in Indian geography: A Country report 2012-2016. New Delhi: Indian National Science Academy.

Shulman, L. S. (1986). Paradigms and research programs in the study of teaching: A contemporary perspective. In M. C. Wittrock (Ed.), Handbook of research on teaching, pp. 3-36. New York: Macmillan.

Shulman, L. S. (1987). Knowledge and teaching: Foundation of the new reform. Harvard Educational Review, 57(1), 1-22.

Subedi, B. P. (2014). The state of geography teaching and research in Nepal: A review and reflection. Kathmandu: Martin Chautari.

Subedi, B.P. \& Joshi. B. D. (1997). About geography in Nepal: An outline for discussion. In Prem K. Katry ed.), Social sciences in Nepal: Some thoughts and search for direction. Kathmandu: Center for Nepal and Asian Studies. pp. 90-112.

Subedi B. P. (2005). A glimpse of geographic research in Nepal: review and reflection. In Subedi, B.P. and Poudel P.C. (eds.), Geography and geographers work in Nepal: Reflections on mountain environment and human activities. Kathmandu: Central Department of Geography, Nepal geographical society, and NCCR north-south, pp. 85-103.

Wiggins, G. \& McTighe, J. (1998). Understanding by design. Alexandria, VA: Association for Supervision and Curriculum Development. 